\title{
Managing Air Pollution in International Environmental Policies: Covid-19 as a Case to Demonstrate the Impact of Human on Environment
}

\author{
Emrah Atar*1 (D)
}

${ }^{1}$ Department of Political Science and Public Administration, Recep Tayyip Erdogan University, Rize, Turkey

\section{Abstract}

Air pollution negatively affects all living and inanimate beings. With the increasing human population, the damage to the environment is increasing every day. The rise of consumption emerged with the increase in the human population. The exploitation of natural resources for competition in the global arena caused nature to be an endless resource. However, nature also has an end; thus, it is not inexhaustible. In recent years, human begins to create living conditions that are compatible with the environment. Air, water, soil, noise, and visual pollution seem to be the most basic environmental pollution types. When studies on air pollution are examined, the emergence of industrialisation has been proved to be one of the first and foremost reasons for pollution. The Covid-19, moreover, reveals the devastating impact of humans on nature. Due to the Covid-19 restrictions, the air quality increased globally in the first few days thanks to decreased human mobility. Therefore, this study will investigate the studies on air pollution in the international arena; examine what kinds of studies are done locally with international attempts with a SWOT analysis, and discuss how the air pollution process is affected significantly during the Covid-19 period.

Keywords: Air pollution, Air quality, International environmental policies, Convention on Long-Range Transboundary Air Pollution, Coronavirus (Covid-19)

Atar, E. (2021). "Managing Air Pollution in International Environmental Policies: Covid-19 as a Case to Demonstrate the Impact of Human on Environment", Journal of Academic Value Studies 7(2) (2021) 63-72 (http://dx.doi.org/10.29228/javs.51632).

\section{Introduction}

With the increase in the world population and the developing technology, the start of the Industrial Revolution in the 18th century has immense importance in the production and economic structure of the countries. However, the establishment of factories with the industrial revolution brought many environmental problems. One of the most critical environmental problems is air pollution. Environmental problems are not local-scale problems but global-scale problems. The deterioration of the ecological balance, which occurs with the increase of environmental problems, has created an unhealthy and poor-quality life. The increase in environmental problems causes these problems to turn into crises. Therefore, there are a long-term, complex, and high-cost situation in ecological subjects. Although there are many causes for air pollution, these can be examined in two groups: naturally occurring air pollution and human-made air pollution (Theodore, 2008; Shahadin et al., 2018). Carbon dioxide, nitrogen oxide and dioxide, chlorofluorocarbons are pollutants caused by artificial air pollution. As a result, Vehicle emissions, fuel oils and natural gas to heat homes, by-products of manufacturing and power generation, particularly coal-fueled power plants, and fumes from chemical production may occur. Natural causes are forest fires, desert dust, and degradation of animal and plant species (Majra, 2011).

The origins of air pollution caused by people are the establishment of many factories with industrialisation and the formation of unplanned urbanisation with the migration from the village to the city due to the need for labouring (Adekola, 2016). Nevertheless, some international initiatives and agreements have been introduced to solve the environmental problems and provide a better quality of life. The Stockholm Conference on the Human Environment, organised by the United Nations in 1972, is among these approaches. The Conference gathered to find solutions to environmental problems occurring on a global scale. Following the Conference, many conventions related

*E-mail address: emrah.atar@erdogan.edu.tr 
to environmental issues have been made. The one related to air pollution is the Convention on Long-Range Transboundary Air Pollution (CLRTAP).

The Convention on Long-Range Transboundary Air Pollution, known as the Geneva Convention, emerged as a result of efforts to prevent transboundary air pollution. The Convention is one of the pioneers in introducing responsiveness to international environmental regimes. CLRTAP can be seen as a contract that aims to solve the region's environmental problems through cooperation and negotiation in the scientific field and brings together the rival parties of the cold war period in this process (Orhan, 2012: 5).

In international organisations, some organisations carry out some programs with air pollution. In order for these initiatives to be successful, detailed studies should be carried out and analysed. A SWOT analysis ought to be done to mitigate the circumstances of air pollution, and measures ought to be taken accordingly. At this point, a SWOT analysis for air pollution was carried out and discussed in this study. Afterwards, the subject of air pollution and coronavirus pandemic, which has been affecting the world especially for the last 1.5 years, will be discussed. As seen that the curfew is one of the most important measures taken during the pandemic. For this reason, the coronavirus pandemic and its relationship with air pollution will be evaluated.

On the other hand, the Covid-19 measures, including a curfew, have twofold importance (Atar, 2021). Firstly, the Covid-19 showed the immense impact of humans on the environment as even a 1-2 months decrease in human mobility increased the air quality. The second importance is the direct relations between air quality and human's health. People who live in high-quality air areas expect to overcome the disease better than the low-quality air areas.

This article consists of four parts in total. Firstly, an evaluation was made on environmental issues and the importance of solving ecological problems in the international arena. Then a discussion about air pollution is presented. In the third part, initiatives against air pollution in the international arena are mentioned; in addition to this, a SWOT analysis of these initiatives is also carried out in this section. In the last part, a discussion is made regarding the case of Covid-19 on the impact of air quality on human beings and the environment.

\section{Environmental Issues and the Importance of Solving Environmental Problems in the International Arena}

Environmental problems have arisen due to the damage to the environment and various human activities. Some of the ecological problems are the deteriorating quality of air, water and soil over time, losing their liveable state, and the extinction of plant and animal types because they are over-consumed for the needs of people (Manisalidis et al., 2020; De Vries and Heij, 1991). Environmental problems may also arise as a result of natural events, but environmental issues are primarily human-induced.

While the environment is necessary for the survival of humanity and all other living beings, environmental problems prevent the environment from renewing itself and its continuity. Environmental issues have ceased to be local and have grown too large to be solved by nations alone (Hardoy et al., 2013), where it has reached a level that will destroy not only humanity but all living species and world life (Dubos et al., 2017). Environmental problems have moved from the micro dimension to the macro dimension and have become global disasters that threaten the world's future. Loss of life and property, material and moral damages began to be expressed in billions. In order to ensure the sustainability of the environment and to solve the existing problems, it has become necessary to take steps to establish an international dialogue; in addition, it has been a positive development that people, who aim to maintain their existence in the world, started to produce policies for today and the future (Kaypak, 2014).

Environmental policies are related to policies to set targets, take measures, and share the burden of these measures to maintain environmental values and eliminate the damage caused by people's excessive consumption by securing the global environment (Martin-Hurtado et al., 2002). It is possible to deal with these problems in different ways while producing solutions related to environmental policies: Kaypak (2014) discusses evaluating the situation alone; a separate resolution is sought for each. Second, to look within the country's integrity; It is possible to implement general policies aiming to change the available settlement order of the country, which forms the basis of all environmental problems in the long term. To look at global integrity, all over the world, human beings act in line with international regulations and are looked after systematically. Therefore, the focus of the problem has shifted from fragmentary to holistic. 
At this point, the importance of solving the environmental problems have globally increased, and different conventions have been put forward in every field, such as the Ramsar Convention on Wetlands of International Importance, Stockholm Convention on Persistent Organic Pollutants, United Nations Framework Convention on Climate Change (UNFCCC) Vienna Convention for the Protection of the Ozone Layer (Swedish Environmental Protection Agency, 2021).

It is acknowledged that the depletion of the ozone layer and the greenhouse effect are the two most important global environmental problems. These two global environmental problems are accepted as indicators of the globalisation process of ecological policies, environmental concern and environmental organisations. These processes can also be considered as indicators that global environmental problems are the direct results of the globalisation of the economic system (Tuna, 2000: 4). As the ecological problems grew and deepened, the borderless nature of the problems was realised, and thus national and international efforts came to the fore to solve the problem (Sipahi, 2010: 333).

The most critical threat to the solution of global environmental problems is that states, which are decisionmaking actors in the international arena, turn this situation into a political bargain with their approach to these problems. Today, the environmental destruction that threatens the future of our world requires the environmental issue to be addressed first. Policies aiming at solving environmental issues, which go beyond the country's borders and have a global character, should also be formed at the worldwide level (Kaypak, 2014). Global environmental governance is also a collective and alternative solution designed to address these essential shortcomings of traditional, local and national governments that are insufficient to address transboundary issues (Sipahi, 2010: 332). Given all these developments, it has been agreed that environmental problems can only be solved in global cooperation with a participatory approach.

\section{Air pollution}

Air pollution can be defined as the amount of matter that air naturally contains in any atmospheric environment that increases for various reasons and reaches a level that will damage living and inanimate beings in the environment (Altıkat et al., 2011: 2). Clean air has an important place for human beings to sustain their lives. However, pollution of air through various ways also lays the foundation for the emergence of respiratory and heart diseases, therefore, the loss of life at an early age.

The causes of air pollution can be categorised under two major factors. The first group is natural causes, and the other is human-made, which arose due to industrialisation and urbanisation (Kök, 2018). With the industrialisation in Britain and developed European countries in the 18th century, the invention of factories, steam engines, and the construction of factories created pressure and danger on nature, natural resources, and people. Installing industrial organisations in the wrong places and not preventing the resulting gases causes air pollution. In addition, of course, industrialisation brings urbanisation. If intensive labour is needed, migration from the village to the cities occurs, resulting in incorrect settlements. Massive urbanization causes the destruction of forests, the transformation of farmland to residential areas and the increased use of coal that are also contributing to air pollution (Zhengfu et al., 2010). The situation in the developed countries are far more worse due to the intense energy use caused by the Industrial Revolution (Krzyzanowski et al., 2014; Chen et al., 1990). Although this ratio is small in undeveloped or underdeveloped countries, it still comes across as a global environmental problem (Ahuja and Tatsutani, 2009). However, air pollution is also augmented by increasing number of motor vehicles per household, and Incorrect burning techniques can be listed as a source of heating during cold weather periods.

\section{Initiatives against Air Pollution in the International Arena}

The limitation of the research on air pollution worldwide, mainly in the formulation of air quality standards, laws, and regulations for resource management implementation, includes measures such as providing health personnel and community health intervention. WHO has prepared several rules for the establishment of air quality standards. In light of these regulations, acceptable maximum standard values are created, while acceptable shortterm limit values are designed to protect at-risk groups and protect the general population, which set annual averages, advised complying with (WHO, 2010). Laws and regulations are being prepared in various countries to function the determined values, and efforts are being made to keep air pollution below WHO's safe limits. 
The United Nations Conference on the Environment, held in Stockholm in 1972, marked the beginning of international work to protect and improve the environment. Since 1972, many international agreements have been made for environmental protection purposes. The European Commission is also in consultation with the oil and motor vehicle industries on significant reductions in fuel consumption to reduce carbon dioxide emissions. It has prepared an "auto-oil" program in collaboration with motor vehicle manufacturers and oil production. In addition, the commission has projected new, low-cost emission confines and fuel eminence standards that will guarantee air quality continues to advance regardless of increased traffic (Arat et al., 2002).

The most important international treaty on air pollution is Geneva Convention on Long-Range Transboundary Air Pollution (CLRTAP) (1979). This contract has an essential place in terms of air pollution exceeding the limits, where it is one of the most critical proofs in cooperation on environmental issues in the international arena. The convention entered into force in 1979, and 8 protocols have been implemented so far (Orhan, 2012).

- Protocol on Long-term Financing of the Cooperative Programme for Monitoring and Evaluation of the Long-range Transmission of Air Pollutants in Europe (EMEP) 1984.

- Protocol on the Reduction of Sulphur Emissions or their Transboundary Fluxes by at least 30 per cent in 1985.

- Protocol concerning the Control of Nitrogen Oxides or their Transboundary Fluxes in 1988.

- Then Protocol concerning the Control of Emissions of Volatile Organic Compounds or their Transboundary Fluxes took place in 1991.

- Protocol on Further Reduction of Sulphur Emissions in 1994.

- Protocol on Heavy Metals in 1998 and its 2012 amended version.

- Protocol on Persistent Organic Pollutants (POPs) in 1998 and its 2009 amended version.

- Protocol to Abate Acidification, Eutrophication and Ground-level Ozone in 1999 and its 2012 amended version.

In addition, an essential agreement on the ozone layer was included in the following years. The Montreal Protocol on substances that devour the ozone layer (Montreal Protocol) is an international agreement concluded in 1987. It is specifically well-thought-out to control the construction and trade-in of substances that damage the ozone layer. The Montreal Protocol was prepared under the Vienna Convention. As a result of the activities that took place in the 1970s and 80s, he found a place in the international arena. The Montreal Protocol has changed over time and has constantly updated itself. Six changes have occurred in this line. Respectively, London 1990, Copenhagen 1992, Vienna 1995, Montreal 1997, Beijing 1999, and Kigali 2016 (Yoshida, 2018).

Although the emergence of the environmental problem is at a local level, its solution needs to be emerged on a global scale. Therefore, it should be shaped around the concept of sustainability. In other words, taking into account both current and future generations, longer-term, global-scale, and less-risk arrangements should be made instead of short-term, local-covering, high-risk contracts. In this context, strengths, weaknesses, opportunities and threats should be determined by SWOT analysis, and air pollution should be minimised by taking various measures in this direction. At this point, it is more imperative to look at the SWOT analysis of the fight against air pollution conducted in the international arena.

Strengths: Educating more conscious individuals about air pollution can help reduce air pollution; it can be seen that achieving this in the international arena is possible in the long term. Spreading the multiplexing of processes where a central system is applied from jobs where low-calorie coals are used can significantly help increase air quality. It is also possible to regularly clean the chimneys in houses with stoves and inform people about this. Factory chimneys should also be filtered, and natural gas use must be encouraged if possible. Reducing the use of special vehicles and making the use of filters necessary for the vehicles used can also help improve the air quality. The removal of industrial facilities from city centres and the levelling of construction in the farthest places from the city can also be seen as a positive approach. Unless a significant problem is encountered, it can be expected that it will be possible to increase the green areas if the works can be done to prevent the green places from being damaged. 
Weaknesses: The existence and multitude of unconscious individuals who do not care about the next generation can be seen as the most critical problem facing us at this point. However, countries' actions in line with their interests also precede the discussion and prevention of environmental issues in the international arena. The abundance of unconscious individuals in society and are unaware of the use of low-calorie coal and the excessive use of materials that can harm environmental problems can be seen as another problem. The fact that society does not always raise awareness and focuses only on its own life to pass the day can be seen as a significant obstacle to the fulfilment of the transactions and creating awareness. The inability to follow a familiar path at a sufficient level to solve the problems may also cause the issues not to be resolved.

Opportunities: Green areas that have never been touched have gained even a little value; thus, international regimes can focus on these areas. Since societies are sufficiently conscious and have a common reaction, it has to be seen as an opportunity to mitigate the circumstances. It shall process the vital importance to a generation through education and training. There is currently an apparent attitude that industries are no longer established in the inner city, which can be used as an opportunity. Sanctions need to be created and replicated while forcing departments on environmental issues.

Threats: The necessary penalties are not applied in the face of environmental problems seem a considerable challenge for the international and national communities and bodies and have penalties that are not sufficient deterrence. Ignoring environmental issues and living a day-oriented life create more problems while facing these issues. Environmental issues do not see a fair value. Concrete steps not been taken ought to be considered as another threat.

Suppose humanity does not take the necessary measures. In that case, environmental problems such as air pollution will put the lives of all living beings in the universe at risk or disappear over time. Thus, the importance to be brought against air pollution is crucial, and the inclusion of all states is also essential for a global dimension. Taking long-term measures while taking actions also allow us to achieve more permanent and fundamentalist results (Vallero, 2014; Boubel et al., 2013). On the other hand, short-term steps are essential in keeping the current situation under control until long-term measures are taken, even if the problems are short-term (Goodland and Ledec, 1987). Scientific studies should be carried out to prevent air pollution, and the international agreements that exist in this direction should become even more deterrent. In order for air pollution to gain a global-scale solution, international air pollution reduction efforts must be supported. It should be specified by measuring the number of air pollutants that can cause harm. It should be activated by determining policies that do not exceed these values by setting new standards that will not exceed the limits.

\section{The Case of Covid-19 on the impact of Air Quality on Human Beings and Environment}

The importance of air pollution can be better understood with the recent coronavirus. Air pollution can cause discomfort in people's respiratory tracts first. Air pollution, moreover, causes severe lung and respiratory diseases, and it has been announced by WHO (2021) that more than 7 million people die from it every year. According to the data, most deaths from countries are seen in undeveloped countries because the first goals of undeveloped countries are to bring themselves to a sufficient level at financial terms; first of all, they have priority issues such as shelter and nutrition, which are their basic needs; thus, nature remains in the second place for many of these countries.

After the emergence of a new Coronavirus in late 2019, which engulfed the entire world in 2020, most countries have taken measures to stop the spread of the virus. Along with these measures, people were forced to stay at their homes, and so many economic activities came to a standstill. With this situation, the need for transport, especially road and air transport, have decreased in parallel. As a result, it is seen that this leads to significant reductions in air pollutant emissions that occur along with transportation. Of course, organisations that temporarily stop their activities are found to have an increase in these emissions again when they start processing.

Air pollution has been at the forefront of many epidemics until today. Air quality, which has a crucial place in almost all field problems, also has an essential position at the point of the spread of epidemics. Chen et al. (2017) discovered that air pollution could accelerate the spread of respiratory infections. Cui et al. (2020) touched on this subject in their research and found that someone living in areas with lower air quality is more than twice as likely to die from SARS than living in a region with cleaner air. Furthermore, Kan et al. (2005), who conducted a study on the SARS epidemic in 2003, referred to the importance of air quality and found that air pollution increased the risk of 
dying from the disease. However, it has been the subject of whether the virus, which is a part of the coronavirus discussions, can be transported on air particles. In their studies on this subject, Zhao et al. (2015) investigated whether particulate substances caused the spread of viruses and mentioned that this could happen, as in the case of bird flu.

As a result of the many pieces of research, it is seen that polluted air increases the risk of further transmission of the virus and the number of cases decreased in countries with clean air, and the number of cases increases in countries with polluted air. China, the country where the virus first appeared, is among the developed countries. It is no coincidence that it is a country with many factories that rapidly increase its industrialisation. Studies show that those who suffer the most from the virus are more affected than those with heart, respiratory and lung diseases before (YIImaz \& Şimşek, 2020). The relationship between the virus and air pollution has recently been witnessed since these disorders are already caused by air pollution.

If a country and region-based analysis is performed on the current pandemic, it is necessary to first look at China, where the virus appeared. In a detailed study by Yang et al. (2020), it was shown that patients with a previous chronic disease need an intensive care unit more than other patients. It is also stressed that the reason for this is due to conditions associated with air pollution. Similarly, Zhu et al. (2020) analysed 120 cities in China and found a significant association between air pollution and COVID-19 infectivity. These results show a meaningful relationship between air pollution and COVID-19 infection, which could partially elucidate the contact of nationwide quarantine and present repercussions for the management and avoidance of this recent infection.

In their study, Wang and Zhang (2020) mentioned that China's air quality had significantly improved, especially in recent years, due to strict emission reduction measures. When coronavirus measures are added to this, it reaches a better level. It was also emphasised that the Chinese government should work harder to win "the battle of blue sky". On the other hand, Gao et al. (2021) noted that air quality has improved following the COVID-19 outbreak, especially in mega-cities in China. In this case, they point out that Wuhan and Beijing are exceptional cases because the increase in air quality in these regions is slower than in the other areas.

In order to examine the changes in air pollutants during the lockdown in more detail, it is necessary to look at the data of many countries. Otmani et al. (2020) showed that air quality measures for the assessment of particulate matter (PM10), nitrogen dioxide (NO2) and sulphur dioxide (SO2) concentrations before and during the lockdown in Salé City dropped drastically. In Delhi, average concentrations decreased by $53.11 \%$ during lockout compared to prelockdown (Mahato et al., 2020). In addition, there was a 35\% diminution in NO2 attentiveness in Almaty, Kazakhstan, during the lockdown (Kerimray et al., 2020). The speed of change in Dhaka City also illustrates a declining appraise of air quality (Rahman et al., 2021). Similarly, metropolitan areas under incomplete lockdown, together with São Paulo, New York, Los Angeles, have undergone a decline in air pollution contrasted to prior years (Chauhan and Singh, 2020).

The air quality in Europe also increased during this period. Figure 1 (EEA Report, Air quality in Europe, 2020) demonstrates the average percentage change in NO2 pollution points from 15 March to 30 April, comparing the observations under the COVID-19 lockdown BAU scenario in Europe agglomerations with more than 0.5 million inhabitants. This estimation demonstrates that the cities with the greatest NO2 concentrations reduction in this period were in Spain (Barcelona: 59 \%, Madrid: 47 \%), Italy (Milan: 54 \%, Turin: 47 \%, Rome and Genoa: 39 \%, Naples: $36 \%)$, France (Marseille: $49 \%$, Nice and Lyon: $34 \%$, Paris: $30 \%$, Lille: $27 \%$ ), Switzerland (Geneva: $47 \%$ ), Turkey (Ankara: $46 \%$ ), Germany (Munich: $37 \%$, Bremen: $36 \%$, Berlin: 33 \%, Hamburg: 28 \%, Frankfurt: $27 \%$ ), the United Kingdom (Bradford: $36 \%$, Manchester: $31 \%$, Glasgow: $29 \%$, London: $26 \%$ ), and Belgium (Antwerp: $29 \%$ ). On the other hand, a few cities seem to have registered an increase (around 10-13\%), for example, Gothenburg (Sweden), Braga (Portugal), Vilnius (Lithuania) and Katowice (Poland). 


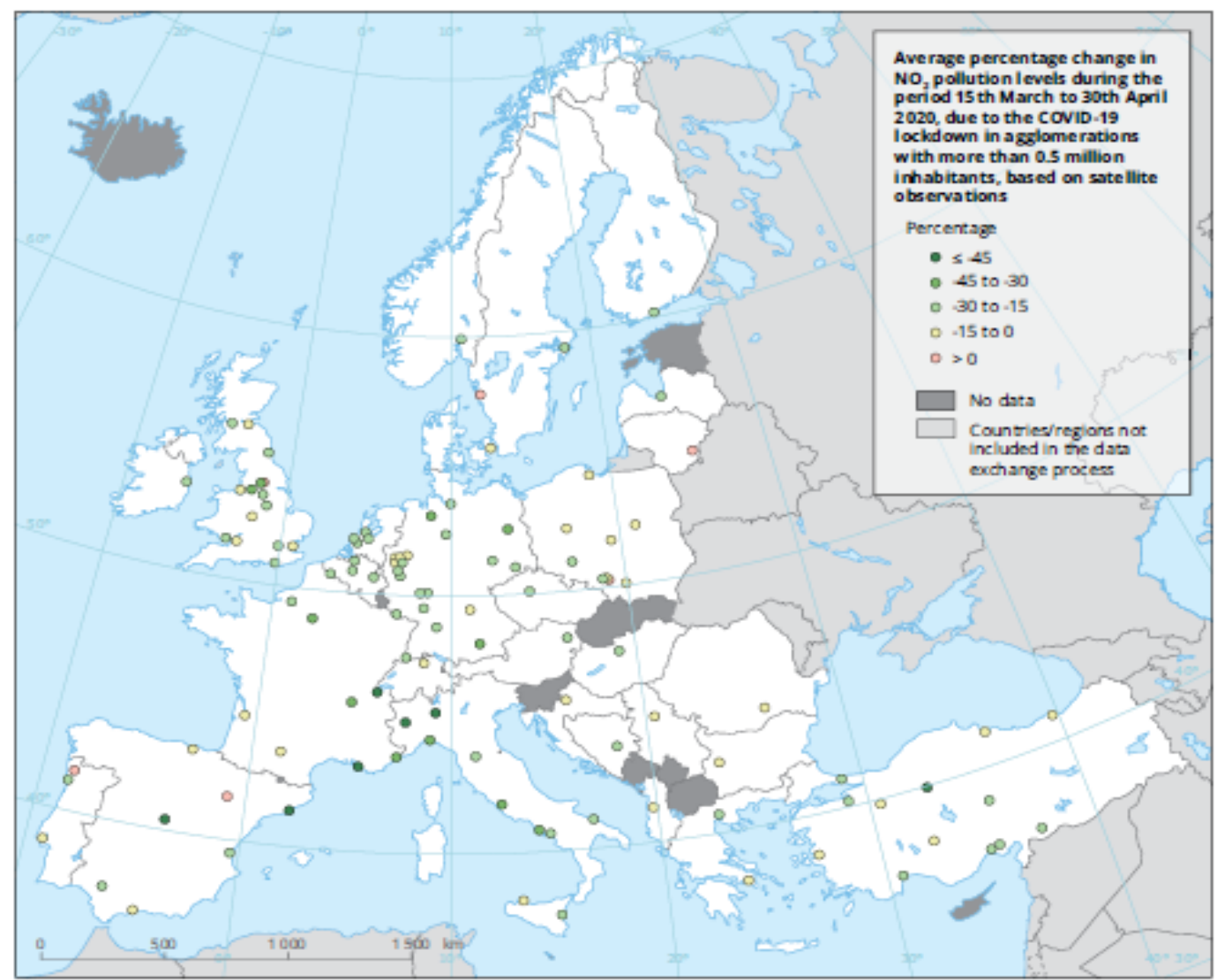

Figure1: Average percentage change in NO2 pollution levels during the period 15 March to 30 April, due to the COVID-19 lockdown.

Source: EEA Report, Air quality in Europe (2020)

\section{Conclusion}

With industrialisation, the need for more energy has emerged. A violation of the ecological balance in the atmosphere is a condition that endangers the lives of all living and inanimate beings, along with the fact that pollutants in the atmosphere are too limited to self-clean. Although natural causes are found among the sources that cause air pollution, the leading manmade causes are industrialisation and urbanisation. Industrialisation brought with its rapid population growth, and urbanisation occurred. As a result, the increase in pollutants in the atmosphere has caused global impacts.

It requires international cooperation in controlling and preventing air pollution. International conventions have also taken steps to avoid air pollution in the short and long terms. In addition, programs related to air pollution are carried out by many international organisations. It is necessary to recognise that environmental problems are a common problem in society. If this value disappears, all living and inanimate beings will be in danger. Being aware of the importance of air pollution and complying with the measures taken against it will stop the threat or cause less harm. In this way, a healthy world and a society will be formed.

Seeing an increase in air quality along with measures taken due to coronavirus actually shows that we can reduce the consequences of this problem by working together. Air pollution, which is one of the critical environmental problems that has increased in recent years, has become one of the even more acute problems today. Air pollution, which expands and continues to increase every day, negatively affects living things and the environment. Rapid population growth, industrialisation, etc., have increased over the years. Such factors lead to an increase in air pollution. Although air pollution continues continuously in the process until today, it has not been raised much. In order to minimise this pollution, various activities are being put forward all over the world.

A prime example of an international initiative is the Long-range Transboundary Air Pollution Convention. In the process that has come to this day, it is necessary to pay more attention to air pollution, which is developing with 
an ever-increasing population and industrialisation. In order to leave clean air not only in the generation but also for future generations, the human being must pay attention to the elements that pollute the air because a healthy future and a clean environment will be possible by minimising air pollution.

On the other hand, the coronavirus has also reduced air pollution during the quarantine processes because people were locked in their homes, most of the factories came to a standstill, and traffic did not commute, in this case, it was scrutinised that air pollution decreased. In addition, NASA shared the values of air pollutants publicly during the corona period. As a result of the collected data, it was examined that air pollution decreased proportionally in developed industrial countries such as China, Europe and the US.

\section{References}

Adekola, P. O. (2016). Migration, urbanisation and environmental problems in Nigeria. Migration and urbanisation in contemporary Nigeria: Policy issues and challenges, 305-3350.

Ahuja, D., \& Tatsutani, M. (2009). Sustainable energy for developing countries. SAPI EN. S. Surveys and Perspectives Integrating Environment and Society, (2.1).

Altıkat, A., Ekmekyapar Torun, F., Turan Bayram, T. (2011). Küresel kirlilik: Dünya, Avrupa Birliği ve Türkiye' de hava kirliliği örneği. Erciyes Üniversitesi Fen Bilimleri Enstitüsü Dergisi, 27(2), 134-149.

Arat, G., Türkeş, M., \& Saner, E. (2002). Uluslararası sözleşmeler ön rapor. Vizyon 2023: Bilim ve Teknoloji Stratejileri Teknoloji Öngörü Projesi Çevre ve Sürdürülebilir Kalkınma Paneli, 1-29.

Atar, E. (2021). An Analysis of Implications of COVID-19 on Forcible Displaced Persons (FDPs). Academia Letters, Article 2015. https://doi.org/10.20935/AL2015

Boubel, R. W., Vallero, D., Fox, D. L., Turner, B., \& Stern, A. C. (2013). Fundamentals of air pollution. Elsevier.

Chauhan, A., \& Singh, R. P. (2020). Decline in PM2. 5 concentrations over major cities around the world associated with COVID-19. Environmental Research, 187, 109634.

Chen, B. H., Hong, C. J., Pandey, M. R., \& Smith, K. R. (1990). Indoor air pollution in developing countries. World health statistics quarterly 1990; 43 (3): 127-138.

Chen, G., Zhang, W., Li, S., Zhang, Y., Williams, G., Huxley, R., ... \& Guo, Y. (2017). The impact of ambient fine particles on influenza transmission and the modification effects of temperature in China: a multi-city study. Environment international, 98, 82-88.

Cui, Y., Zhang, Z. F., Froines, J., Zhao, J., Wang, H., Yu, S. Z., \& Detels, R. (2003). Air pollution and case fatality of SARS in the People's Republic of China: an ecologic study. Environmental Health, 2(1), 1-5.

De Vries, W., \& Heij, G. J. (1991). Critical Loads and Critical Levels for the Environmental Effects of Air Pollutants. In Studies in Environmental Science. 46, 205-214.

EEA Report, (2020). Air quality in Europe. Retrieved 20 April 2021, from https://www.eea.europa.eu/publications/airquality-in-europe-2020-report

Gao, C., Li, S., Liu, M., Zhang, F., Achal, V., Tu, Y., ... \& Cai, C. (2021). Impact of the COVID-19 pandemic on air pollution in Chinese mega-cities from the perspective of traffic volume and meteorological factors. Science of The Total Environment, 773, 145545.

Goodland, R., \& Ledec, G. (1987). Neoclassical economics and principles of sustainable development. Ecological Modelling, 38(1-2), 19-46.

Hardoy, J. E., Mitlin, D., \& Satterthwaite, D. (2013). Environmental problems in an urbanising world: finding solutions in cities in Africa, Asia and Latin America. Routledge.

Kan, H. D., Chen, B. H., Fu, C. W., Yu, S. Z., \& Mu, L. N. (2005). Relationship between ambient air pollution and daily mortality of SARS in Beijing. Biomed Environ Sci, 18(1), 1-4. 
Kaypak, Ş. (2014). Çevre Sorunlarının Çözümünde Küresel Çevre Politikaları. Muğla Üniversitesi Sosyal Bilimler Enstitüsü Dergisi, (31), 17-34.

Kerimray, A., Baimatova, N., Ibragimova, O. P., Bukenov, B., Kenessov, B., Plotitsyn, P., \& Karaca, F. (2020). Assessing air quality changes in large cities during COVID-19 lockdowns: The impacts of traffic-free urban conditions in Almaty, Kazakhstan. Science of the Total Environment, 730, 139179.

Kök, F. (2018). Kentlerde Hava Kirliliğini Önleyecek ya da Azaltacak Yöntem İçin Verilerin Toplanması ve Değerlendirilmesi. Ulusal Çevre Bilimleri Araştırma Dergisi, 1(3), 145-157.

Krzyzanowski, M., Apte, J. S., Bonjour, S. P., Brauer, M., Cohen, A. J., \& Prüss-Ustun, A. M. (2014). Air pollution in the mega-cities. Current Environmental Health Reports, 1(3), 185-191.

Mahato, S., Pal, S., \& Ghosh, K. G. (2020). Effect of lockdown amid COVID-19 pandemic on air quality of the mega-city Delhi, India. Science of the Total Environment, 730, 139086.

Majra, J. P. (2011). Air quality in rural areas. In Chemistry, Emission Control, Radioactive Pollution and Indoor Air Quality. Intechopen.

Martin-Hurtado, R., Bolt, K., \& Hamilton, K. (2002). The environment and the millennium development goals (No. 25399, p. 1). The World Bank.

Orhan, G. (2012). Hava Kirliliği ve Asit Yağmurlari: Uzun Menzilli Sinirlar Ötesi Hava Kirliliği Sözleşmesi ve Protokolleri Karşisinda Türkiye'nin Konumu. Marmara Üniversitesi Avrupa Topluluğu Enstitüsü Avrupa Araştırmaları Dergisi, 20(1), 123-150.

Otmani, A., Benchrif, A., Tahri, M., Bounakhla, M., El Bouch, M., \& Krombi, M. H. (2020). Impact of Covid-19 lockdown on PM10, SO2 and NO2 concentrations in Salé City (Morocco). Science of the total environment, 735, 139541.

Rahman, M. S., Azad, M. A. K., Hasanuzzaman, M., Salam, R., Islam, A. R. M. T., Rahman, M. M., \& Hoque, M. M. M. (2021). How air quality and COVID-19 transmission change under different lockdown scenarios? A case from Dhaka city, Bangladesh. Science of The Total Environment, 762, 143161.

Shahadin, M. S., Mutalib, N. S. A., Latif, M. T., Greene, C. M., \& Hassan, T. (2018). Challenges and future direction of molecular research in air pollution-related lung cancers. Lung Cancer, 118, 69-75.

Sipahi, E. B. (2010). Küresel çevre sorunlarına kolektif çözüm arayışları ve yönetişim. Selçuk Üniversitesi Sosyal Bilimler Enstitüsü Dergisi, (24), 331-344.

Swedish Environmental Protection Agency. (2021). International environmental conventions. Retrieved 5 July 2021, from https://www.swedishepa.se/Environmental-objectives-and-cooperation/Cooperation-internationally-andin-the-EU/International-cooperation/International-environmental-conventions//

Theodore, L. (2008). Air pollution control equipment calculations. John Wiley \& Sons.

Tuna, M. (2000). Çevresel Sorunların Küreselleşmesi. Muğla Üniversitesi SBE Dergisi, 1 (2), 1-16.

Vallero, D. (2014). Fundamentals of air pollution. Academic Press.

Wang, X., \& Zhang, R. (2020). How Did Air Pollution Change during the COVID-19 Outbreak in China?. Bulletin of the American Meteorological Society, 101(10), E1645-E1652.

WHO, Ambient air pollution. (2021). Retrieved 1 April 2021, from https://www.who.int/data/gho/data/themes/topics/topic-details/GHO/ambient-air-pollution

World Health Organization. (2010). WHO guidelines for indoor air quality: selected pollutants.

Yang, J., Zheng, Y. A., Gou, X., Pu, K., Chen, Z., Guo, Q., ... \& Zhou, Y. (2020). Prevalence of comorbidities and its effects in patients infected with SARS-CoV-2: a systematic review and meta-analysis. International Journal of Infectious Diseases, 94, 91-95.

Yılmaz, V., \& Şimşek, T. (2020). Hava Kalitesi ile Covid-19 Arasındaki İlişki: G-7 Ülkeleri Üzerine Bir Uygulama. Electronic Turkish Studies, 15(4). 
Yoshida, O. (2018). The Montreal Protocol: the Evolution of the International Regulatory Régime for the Protection of the Ozone Layer. In The International Legal Régime for the Protection of the Stratospheric Ozone Layer (pp. 97159). Brill Nijhoff.

Zhao, Y., Richardson, B., Takle, E., Chai, L., Schmitt, D., \& Xin, H. (2019). Airborne transmission may have played a role in the spread of 2015 highly pathogenic avian influenza outbreaks in the United States. Scientific reports, 9(1), 1-10.

Zhengfu, B. I. A. N., Inyang, H. I., Daniels, J. L., Frank, O. T. T. O., \& Struthers, S. (2010). Environmental issues from coal mining and their solutions. Mining Science and Technology (China), 20(2), 215-223.

Zhu, Y., Xie, J., Huang, F., \& Cao, L. (2020). Association between short-term exposure to air pollution and COVID-19 infection: Evidence from China. Science of the Total Environment, 727, 138704. 